\title{
VIEWPOINTS
}

\section{Debt Management with a Conscience}

\author{
Mohammad Hashim Kamali ${ }^{*}$
}

The inner stability and resilience of Islamic finance will not hold, and the low risk element therein is bound to diminish unless the $\operatorname{sharī~}^{\prime} a h$ principles are diligently observed.

The world experienced two major financial crises within a decade: the currency and stock market crises of 1997-98, and now a crippling recession that began with the US subprime debacle caused by excessive lending to borrowers unable to make repayment. Both originated in 'asset bubbles' and unlimited creation of fiat money that loaded the market with the sale of debts, or bay 'al-dayn, as it is known in the jargon of sharì 'ah law. Dealing in debts that lacked any asset base overwhelmed the financial system.

Transactions in derivatives and contra trading in stocks proceed largely over debts that are bought and sold through mere exchange of promises by speculators and hedge funds that take risks far in excess of their available assets. It is different in Islamic finance, which is structurally averse to indulgence in debt-based transactions.

The capitalist banking and financial institutions, moreover, make profits but have no mechanism to share possible losses. A different scenario exists in Islamic finance, which favours equity financing, in which the parties involved share the prospects both of profit and loss.

Islamic finance transactions also proceed over underlying assets, trades and services that hold real market value. Pure unsecured debt plays a minimal role, essentially confined to an act of goodwill or qard hasan, without a commercial prospect. The half-a-dozen or so contracts in use in the Islamic system proceed over trades and services, as in the case of mushārakah and mud̄arabah, which consist of participation finance, profit and loss sharing. Banks and financial institutions that enter these contracts effectively become partners in a project and hold a stake in both its failure and success.

* Prof. Dr Mohammad Hashim Kamali is the Chairman and CEO of IAIS Malaysia. An earlier version of this viewpoint appeared in Kuala Lumpur's English-language daily The New Straits Times on 8 July 2009. 
Islamic finance admittedly permits debt-based transactions, which are, however, limited to situations where only one of the two counter-values consists of a debt. For example, in bay' bi-thaman 'ajil, or deferred sale, only the price, but not the sale object, consists of a debt. Since a sale takes place over a real asset, such as a building or a plant, the debt in question is asset-based and proportionate to the price of the sold item. This is also the case in the forward sale of salam, in which only the sale object, but not the price, consists of a debt. All the contractual details of the debt in salam must be specified in writing to ensure commitment, proportionality and equivalence in the exchange of values.

Shari 'ah law does not approve of a financing scheme in which both the countervalues consist of debt. A difference of opinion has thus arisen over the validity of istișna ${ }^{\prime}$, or manufacturing contract, whereby an order is placed for the manufacture of goods, be it a house, ship or handicraft. Nothing changes hands at the time of contract, and both sides of the bargain consist of debts payable in the future - which is why Muslim jurists have considered istișn $\bar{a}^{\prime}$ as basically ultra vires. Yet istișna ${ }^{\prime}$ has been exceptionally validated by consensus because of the people's need for it.

A similar line of analysis can be extended to the entire range of contracts that represent the bulk of Islamic banking and finance transactions. Murābahah or costplus-profit sale, which is very common, may or may not involve a debt as it can be spot or deferred. Only when deferred does it involve a debt, in which case it would resemble bay' bi-thaman 'ajjil. The contract of wadì'ah or deposit, also widely practised, does not involve either a debt or exchange of values and is therefore free of financial speculation and risk-taking.

Since sharī ah law proscribes the giving and taking of banking interest, or indeed of any unwarranted increase that violates the principle of equivalence in counter-values, sharī'ah-compliant transactions are less vulnerable to interest-rate fluctuations.

The shar ' $a h$ is similarly averse to excessive risk-taking (gharar) that threatens due fulfilment of contractual obligations, especially in deferred and forward sales, which involve debt. The applied rules of Islamic law limit exposure to risk, in that a transaction is not permitted with a company or institution whose balance sheet consists of debt that exceeds 50 per cent of its total available assets. This is a major restraint that curbs asset bubbles of the kind that continue to plague contemporary finance.

These are some of the in-built elements of stability in Islamic finance that are generally absent in their conventional counterparts. Yet, the advantages of Islamic finance can only materialise when compliance with sharī ah principles is assured, which is not always the case. Many contract specifications are followed in form but not in spirit by the Islamic financial institutions.

For instance, the detailed requirements of delivery and possession are often ignored, and buying and selling take place in the same session. Muräbahah is thus 
manipulated for the purpose mainly of securing the price differential, or mark-up, which is made payable at a later date, and the net result is not very different from earning interest on a conventional loan.

Similarly, the very commonly practised sell-and-buy-back transaction of 'inah often consists of a price differential in the same session and a quick profit-taking that resembles ribā.

Formal compliance that amounts to effective non-compliance has thus aroused much criticism among Muslims, who go to Islamic banks often with pious motives to avoid the forbidden $r i b \bar{a}$, but remain askance about whether the Islamic banks really measure up to their expectations.

These institutions are, like their conventional counterparts, eager to lend as much as possible and gain as much profit as they can. The inner stability and resilience of Islamic finance will not hold, and the low risk element therein is bound to diminish unless the shari ${ }^{-} a h$ principles that regulate such transactions are faithfully observed. 